\title{
Adaptive Reuse of Manor Houses: Modernism and Tradition in Fernando Távora's Approach for Heritage Renovation
}

\author{
David Ordóñez-Castañón $^{1 *}$, Teresa Cunha-Ferreira ${ }^{2}$, Santiago Sánchez-Beitia ${ }^{1}$ \\ ${ }^{1}$ School of Architecture, University of the Basque Country UPV/EHU, Plaza Oñati 2, San Sebastián 20018, Spain \\ ${ }^{2}$ School of Architecture, University of Porto (FAUP), Via Panorâmica Edgar Cardoso 215, Porto 4150-564, Portugal
}

Corresponding Author Email: david.ordonez@ehu.eus

https://doi.org/10.18280/ijsdp.160318

Received: 17 January 2020

Accepted: 20 April 2021

\section{Keywords:}

adaptive reuse, landscape, restoration and conservation, modern architecture, Fernando Távora, Portugal

\begin{abstract}
This article seeks to analyze the methodology and principles underlying the intervention of the Portuguese architect and professor Fernando Távora (1923-2005) in the renovation of manor houses in the north of Portugal. Throughout his renowned professional career, Távora designed the refurbishment of numerous country houses, managing to adapt uses and spaces to the new requirements without undermining their strong identity in the landscape and their historical and architectural values. Thus, the study of his particular methodology can provide design guidelines to approach the adaptive reuse of this cultural legacy with respect for its heritage values, especially in rural areas undergoing a severe process of depopulation and agroproductive transformation. Three case studies have been selected in order to determine the evolution and consolidation of his practice: The Casa da Igreja in Mondim de Basto (19581961), the Casa da Covilhã (1963-1988) and the Casa da Breia (1984-1985). These renovation projects reveal careful analysis of the preexistence, supporting sensitive introduction of new elements with subtle contemporary expression in respectful continuity with the forms and atmospheres of the past.
\end{abstract}

\section{INTRODUCTION}

Due to the deep social and agricultural changes that have affected the countryside in recent decades, many rural buildings, among which the historic manor houses, have been abandoned or have been subjected to inadequate transformations. The migration of owners to the cities, the high maintenance costs or even disagreements in the distribution of inheritances are some of the many causes leading to the gradual neglect and subsequent ruin of some of these country houses. Nevertheless, many others have endured thanks to the flexibility of this architectural typology, which, because of its generous areas and functional organization, supports the adaptation for diverse uses. In some cases, residential utilization has been maintained after making modifications in order to incorporate the latest functional advances and comfort improvements required by current lifestyles. Others have been transformed into tourist accommodations, company headquarters or even into public facilities. However, it is not always simple to adapt these old buildings, so unfortunately some renovations are not able to respect the historical and architectural values.

The professional career of the Portuguese architect and professor Fernando Távora (the mentor of Pritzker Prize winners Álvaro Siza and Eduardo Souto Moura, among other architects of the so-called Porto School) has given consistent contributions in the field of restoration and conservation of architectural heritage. Some of his most valuable interventions in built heritage were renovations of houses in the countryside [1]. These examples show a sensible adaptation of spaces and forms to new functions while preserving the memory of the pre-existing building, its constructive values and its strong identity in the landscape.

Távora was particularly sensitive to rural constructions largely due to his own cultural and social background. His family belonged to an ancient lineage and his parents owned several manor houses, where he grew up, in contact with the typical activities of the countryside. In his own words, the manor houses between the Douro and Minho rivers "represent an interesting type of Portuguese rural architecture, either by its character or by its identity. Belonging, for the most part, to a historical period marked by the gold and diamonds from Brazil and by corn cultivation as decisive factors of its economy, these buildings reveal the existence of a rural nobility of sober life, proud of their ancestry, and of simple but cultured local labour" [2].

Hence, this architectural typology is generally defined by its privileged setting in the landscape (so to be seen and to control the surrounding fields) and by the scenographic character of its main façade marked by axial or symmetric composition, frequently underlined by elements such as staircases, fountains, vegetation and decoration. Moreover, in functional terms, the representative and reception spaces are related to the main façade, while private apartments or service uses such as kitchens are faced to the back. In the interior, social reception compartments tend to be organized in an enfilade distribution system and have high architectural and artistic prominence, namely in fireplaces, ceilings, furniture, etc.

The aim of this article is to define the patterns of his design methodology when renovating stately houses. Hence, the application of Távora's lessons can provide guidelines for the future conservation and adaptive reuse of these important 
permanencies in the landscape, not only in Portugal but also in other similar contexts.

\section{RESEARCH METHODOLOGY}

\subsection{Information sources}

The research methodology of this paper is based on bibliographic and, particularly, archival research. The materials examined in the archives have been both graphic (sketches, plans, elevations, sections, construction details, etc. of the previous studies and of the execution project), photographic (of the previous state, of the work and of the current state) and textual documents (descriptive report, reflections of the author, publications...). Although municipal and private archives have been consulted, the greatest amount of primary information was extracted from the professional archive of the architect, hosted by the Marques da Silva Institute Foundation (FIMS) in Porto, which is composed of over three hundred architectural and urban planning projects. It also comprises his personal library, composed of more than six thousand volumes, covering multiple subjects in different languages (including traditional architecture, the history of architecture and human geography, among others) and revealing the profound cultural knowledge of the architect. Besides his architectural drawings, FIMS also preserves many photographs, personal notebooks, travel sketches, models, executive documents, budget estimations, letters, etc.

The study of archival documentation was further complemented by field research, involving direct observation of the works (systematic photographic surveys, drawings and notes), as well as by interviews to both the owners and with Távora's collaborators who were directly involved in each specific project. Furthermore, the works were analyzed and interpreted using drawing as a research tool (geometrical studies, yellow-red color survey, constructive details, etc.).

\subsection{Structure and analysis parameters}

This paper provides a background on the national and international architectural context, highlighting some of the most significant factors that influenced the development of Távora's methodologic framework. This outline makes available the context for the analysis of the principles underlying the intervention in the renovation of manor houses through the study of three representative projects.

Each case has been dissected according to common analysis guidelines. The defined parameters seek to describe each stage of the intervention process, establishing a sequence that allows documenting both the state prior to the intervention, as well as the design of the operation and the execution of the works:

(1) Characterization of the pre-existing building, namely the aspects related to its cultural context (historical, genealogical, typological, landscape, etc.) as well as its state of conservation prior to the intervention.

(2) Study of the intervention strategy, regarding the adaptation of previous spaces to incorporate new functions, as well as other preservation and transformation actions. This parameter also involves the aspects concerning the relationship between new and old, especially at their points of contact, and the mechanisms of interaction (mimesis, analogy, contrast, continuity, abstraction...).

(3) Analysis of the construction process and the details, that is, everything concerning the tectonic and constructive features, the choice of materials and techniques, finishing details and restoration of furniture, decoration, etc.

The same parameters have been used in the subsequent phase to discuss the common features (and diverging nuances) in order to draw some conclusions about Távora's approach to the renovation of manor houses.

\section{BACKGROUND}

\subsection{National architectural context}

The publication of the essay $O$ problema da casa portuguesa (Fernando Távora, 1945) and the celebration in 1948 of the I Congresso Nacional de Arquitectura opened a new a stage in Portuguese architecture characterized by the search for new formulas capable of integrating the achievements of the Modern Movement and the values of history and tradition. The reaction of the young architects arose as a protest against the revivalist architecture supported by the dictatorship of António Salazar (which, at the same time, blocked the development of modern architecture).

Moreover, Távora was deeply committed to the study of Portuguese traditions and was one of the driving forces behind the Inquérito à Arquitectura Popular em Portugal (Survey on Popular Architecture, 1956-1961) [3]. He led the group of architects form the Minho region, who undertook an enormous fieldwork to record the vernacular architecture of the area (through photographs, drawings, sketches and annotations) (Figure 1). Therefore, the theoretical a practical proposal for a "third way", formulated among others by Fernando Távora, sought to launch an alternative capable of reconciling the principles of the Modern Movement with the values of local architecture, in such a way that it was possible to update living standards without renouncing the national identity.

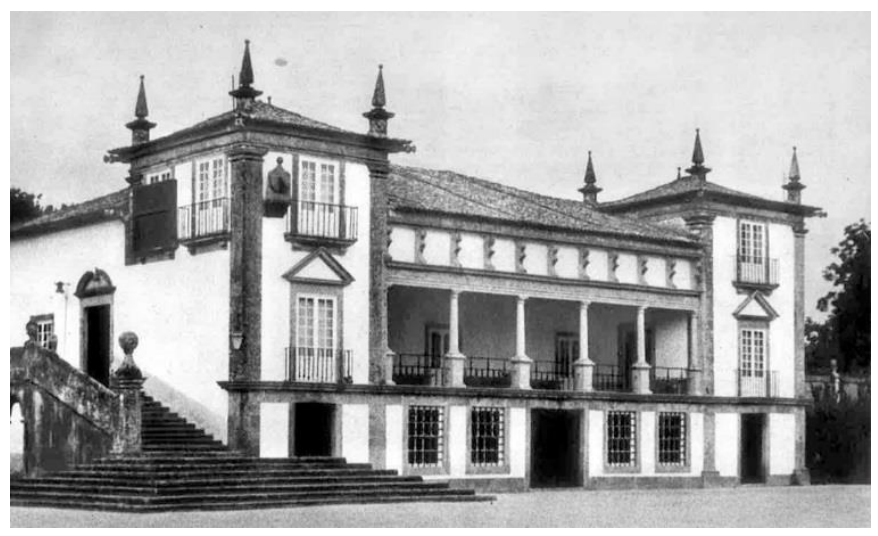

Figure 1. Solar de Bertiandos (Ponte de Lima), one of the baroque manor houses documented in the Inquérito

\subsection{International architectural context}

Fernando Távora's attendance to some of the latest CIAM made him aware of the change in direction taken by the European architectural avant-garde. The youngest attendees, founders of the Team X, criticized the homogenization of the International Style and advocated a return to considering the specific conditions of each particular (cultural, historical, geographical, climatic, etc.) context. Távora was also able to interact with other colleagues, who were similarly interested 
in issues related to the contemporary creation in a historical context, such as Ernesto Nathan Rogers. Both could share the ideas on the respect for environmental preexistence and the case-by-case approach. Numerous reflections by the Italian theorist on the need to establish continuity between personal creation and the presence of tradition left a powerful mark on the Portuguese architect.

For its part, the genuine Brazilian modernism also had a great impact on young Portuguese architects due to the dissemination of the catalog of the exhibition Brazil Builds: architecture new and old, 1652-1943, shown at MoMA [4]. This book showed an architecture directly related to Le Corbuiser, but duly adapted to local singularities through the creative reinterpretation of elements and materials taken from vernacular construction. In addition, it showed that modern creation did not reject historical architecture; in fact, it suggested that the joyful and sensual curves of Oscar Niemeyer's buildings established a historical connexion with the dynamism of the colonial baroque. Besides, Lucio Costa's theories and experiences at the National Historical and Artistic Heritage Service (SPHAN) preceded several features of Fernando Távora's method of restoration. At the Museu das Missões (1940), Costa freely merged different criteria in the same work, combining a controversial anastylosis of the veranda to recover the hypothetical primitive image of the building (stylistic restoration), with the introduction of modern elements (contemporary creation) and with the arrangement of archaeological remains for an evocative purpose (Romantic poetics of the ruins)

\subsection{Fernando Távora and the "third way"}

Távora's sensitivity towards vernacular architecture was reflected in ex novo works, such as the tennis pavilion of the Quinta da Conceição and the Casa em Ofir (1956-1958) [5]. No less important however was the proposal of an innovative approach to interventions in the historical heritage. The relationship between "new" and "old", a question that was raised by Távora, began to move away from the traditional dichotomy between the Romantic principles of nonintervention and stylistic restorations. Until then, the prevailing praxis in Portugal, strongly conditioned by the ideology of the Estado Novo, was the repristination. The guidelines provided by the Direção-Geral dos Edificios e Monumentos Nacionais (DGEMN) prescribed a mimetic language, with the aim of restoring idealized primitive forms in the monument [6].

In this respect, Távora forged a new approach to heritage intervention methodology and criteria in Portugal. His personal modus operandi first became visible at the end of the 1950's at experimental refurbishments such as the Casa do Além (1956-1967) and the Casa da Igreja (1958-1961) and later developed in other renovations with strong repercussion and pedagogy in the Portuguese context [7]. The expansion of the Pousada de Santa Marinha da Costa (1972-1985), the Escola Superior Agrária de Refóios do Lima (1987-1993) and the Casa da Rua Nova (1985-1987) can be highlighted. According to Távora's statement for Santa Marinha da Costa Monastery, "the general criterion adopted in the project [...] was to 'continue innovating' or, in other words, to continue contributing to the long life of the building, by conserving and strengthening its most significant spaces or creating qualified spaces determined by the conditions of their new function. The intention was to create a dialogue, highlighting the affinities and the continuity rather than the differences and the break from the past" [8].

\section{CASE STUDIES}

\subsection{Selection of the case studies}

Throughout his prolific professional career, Fernando Távora designed more than seventy projects between renovations of old buildings and urban regeneration plans in historic centers. Twenty of those are projects for the refurbishment and reuse of manor houses. This paper will analyze, compare and discuss three representative cases, which demonstrate the existence of common features between the works. The criteria of selection of the proposed examples is based on a combination of several factors:

(1) The selected works are those that, as judged by the authors, most clearly reflect the way in which Fernando Távora operates in traditional constructions, in terms of both the design process, the constructive execution and the result achieved. All of them meet the premises of being visitable and sufficiently documented through archival documentation, oral testimonies, published works or other sources of information.

(2) Moreover, these projects cover a broad chronology, from Távora's professional youth to his period of maturity, thus allowing for the comprehension of the evolution of his approaches and methodologies. The Casa da Igreja of Mondim de Basto (1958-1961) represents a germinal essay of his principles of heritage intervention, while the renovation of the Casa da Breia (1984-1985) is a work where the methodological procedures on the relationship between new and old are fully accomplished. In between, the Casa da Covilhã (1963-1988) is a singular work that lasted for decades (it was his own house), which served as a design laboratory to test procedures that were successfully applied in later renowned renovations.

(3) In addition, priority has been given to the study of little-known, or even unpublished works, which illustrate other facets and bring new interpretations of Távora's attitude when intervening in the built environment. Indeed, the Casa da Igreja and the Casa da Breia are scarcely published, despite their relevance and interest in the scope of this research. Therefore, in spite of Távora's work wide diffusion and recognition, the study of these cases fills a gap in the knowledge of his practice.

(4) The selected projects were all executed, having discarded others that, notwithstanding their interest, were never built. Among them, it is worth mentioning the Casa da Quinta da Boavista (1973-1974), the Solar do Vinho do Porto (1974-1975) or the Casa de Vila Boa (1991), as well asCasa da Quinta da Várzea (1990-1994), a rare case in which the architect demolished the old manor house.

Furthermore, the chosen cases have not been subject to significant alterations after Fernando Távora's renovation, so it is easier to interpret the work performed by the architect. However, the state of preservation is uneven (the Casa da Igreja shows a worrisome deterioration).

\subsection{Casa da Igreja (Mondim de Basto, 1958-1961)}

\subsubsection{The pre-existing building}

The Casa da Igreja is settled next to the parish church, in a former farming land, distanced from the medieval urban core 
of the town. There are documentary references since 1575 , although the current building dates from the last quarter of the 18th century, according to the historical documentation and its morpho-typological characteristics. The main façade exhibits a harmonious formal composition, following the patterns of the Portuguese Baroque. While the front courtyard is a representative garden (based on traditional boxwood and camellia topiaries), the backyard was originally a space intended for different activities of the domestic service and for agricultural works. In fact, the rear façade has been subject to successive alterations throughout $19^{\text {th }}$ and $20^{\text {th }}$ century, as functional needs arose (pigsties, henhouse, storerooms, etc.).

\subsubsection{The intervention strategy}

In 1958, Mr. Antonio Lage entrusted Fernando Távora with the renovation project. The conservation status of the building at that moment is currently unknown. Anyhow, an in-depth reform was undertaken, as the architect stated: "The work was total, keeping everything in the building. The work was total, keeping everything that really possessed character and that was not 'pastiche"' [9].

Indeed, the work was of great magnitude since the mansion was entirely renovated (Figure 2). These changes affected even the floor slab (rebuilt in reinforced concrete), the roof (new wooden frame and tiles) and, specially, the rear façade, which was deeply renewed. In addition, the arrangement of the interior was largely modified in order to achieve domestic spaces with modern facilities.

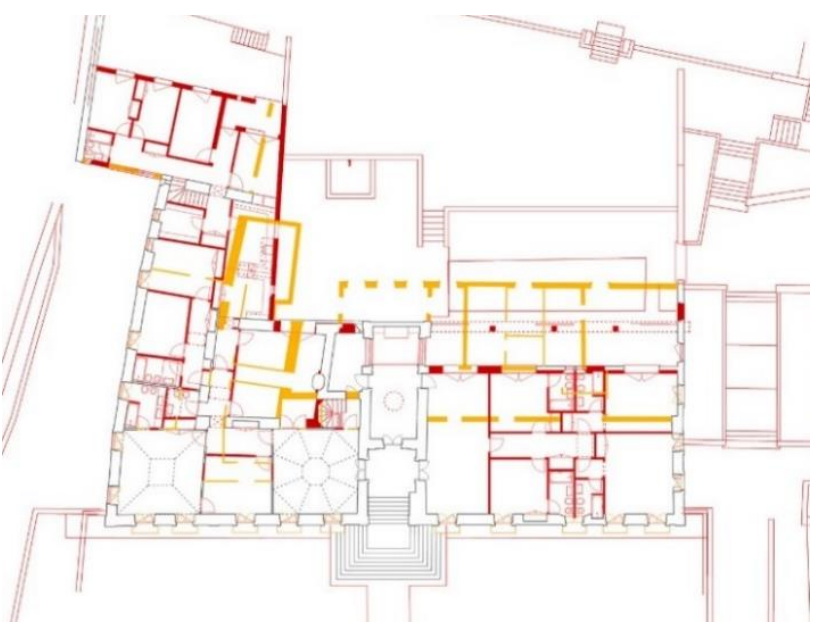

(a) Analysis of transformations

(yellow: demolished elements; red: new elements)

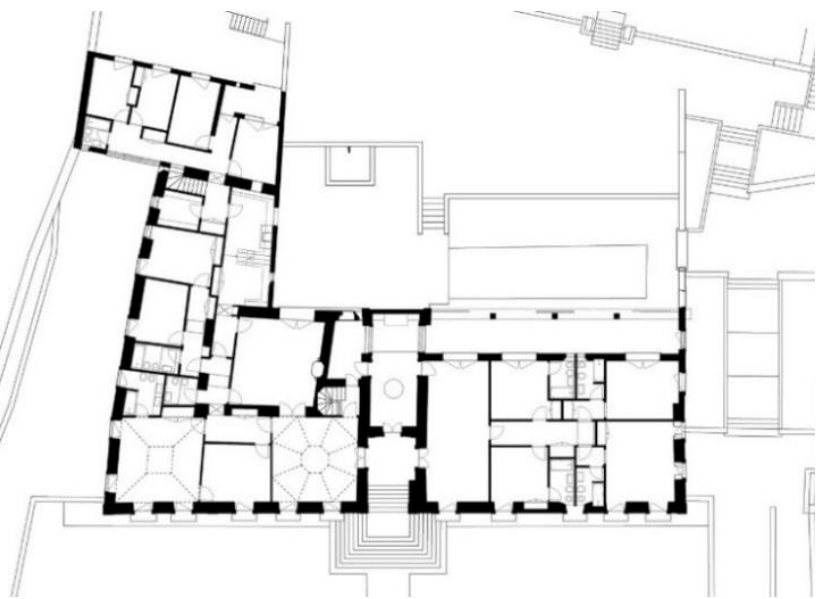

(b) Final state

Figure 2. Casa da Igreja. Plan of the main floor

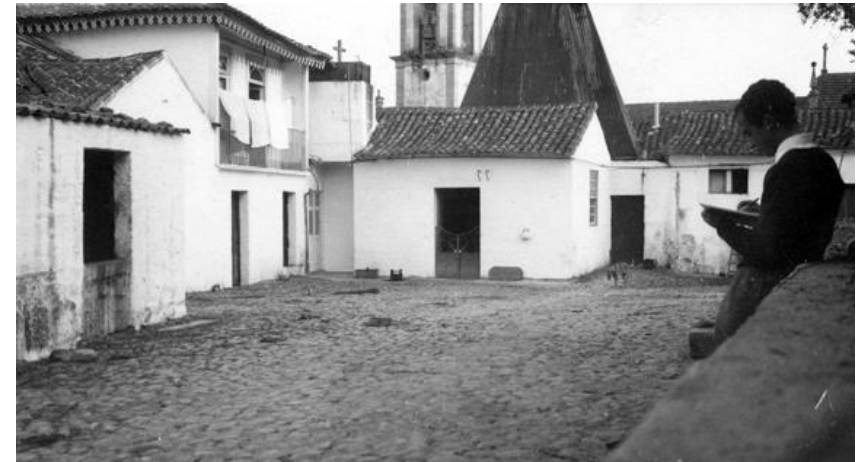

(a) Circa 1940. Fernando Távora drawing in the rear patio, years before the renovation project [7]. CFundação Marques da Silva, Arquivo Fernando Távora

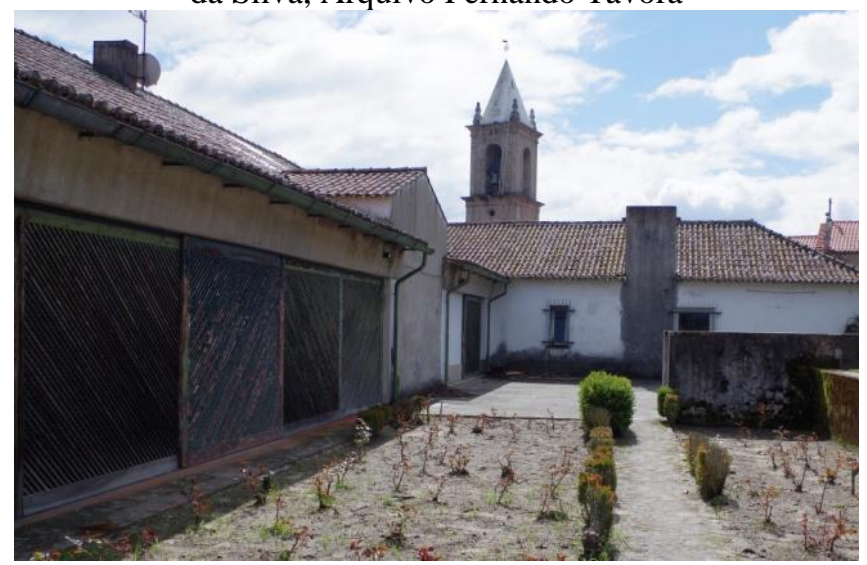

(b) Current state [7]

Figure 3. Casa da Igreja. Rear façade

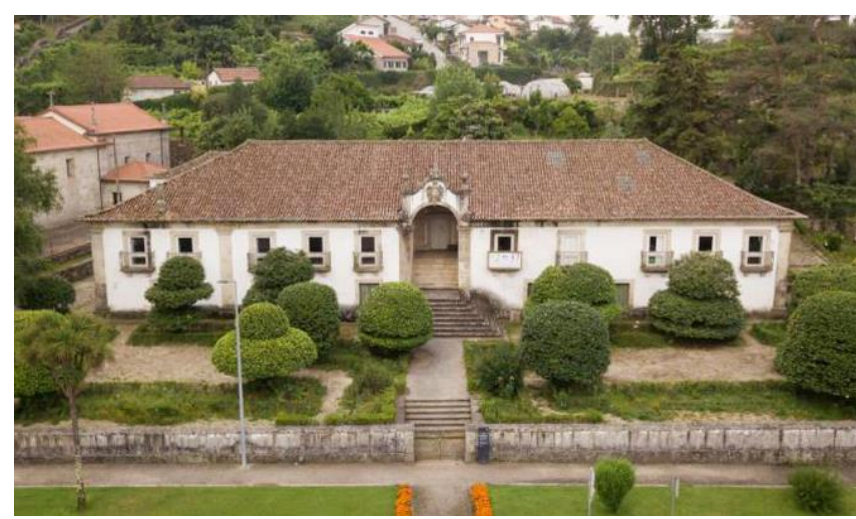

(a) Main façade (Câmara Municipal)

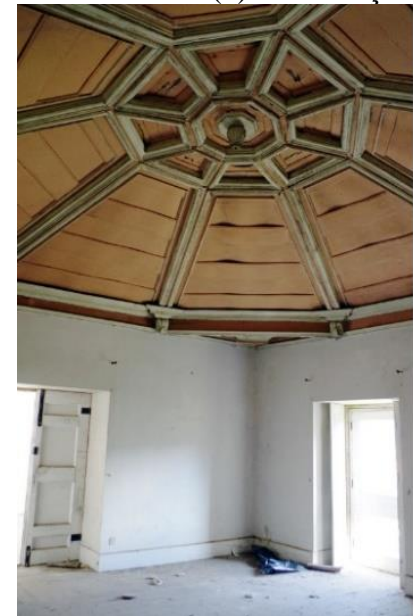

(b) Main hall [7]

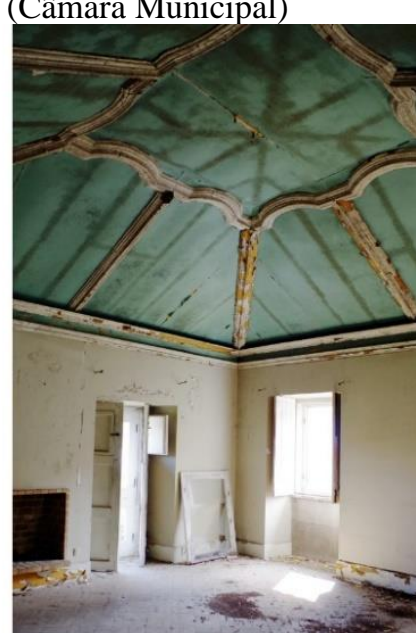

(c) Master bedroom [7]
Figure 4. Casa da Igreja. Images of the current state 
This project can be considered an essay of Távora's modus operandi of heritage renovation. The architect himself acknowledges to be exploring a model of intervention different from the usual one: "what was important in this work was to establish a restoration criterion different from that which was currently being used [...]. I tried to use a 'healthy' restoration criterion: neither denying the past, nor attempting to rehash it" [9]. This statement has to be understood in the context of the "third way", at a time when the artificial use of elements of tradition was strongly rejected and the influence of the Modern Movement was very strong. In this sense, what was built ex novo had to intensely express its contemporaneity, making use of new materials but seeking, at the same time, the best possible relationship with the forms of the past. According to the architect, the aim was to establish "a dialogue with our heritage by means of current day style, obtaining in this synthesis of styles a fresh and cheerful work" [9].

The reform of the rear facade is an eloquent reflection of this attitude (Figure 3). Távora was aware that the $19^{\text {th }}$ century additions had distorted the physiognomy of the house. His purpose was to recover the previous profile, highlighting the figure of the chapel as the heart of the building, and to give this façade a unitary image as well as its own identity within the whole. This approach may be interpreted as a repristinating (an effort to recover a hypothetical original state, disregarding later accretions), but, actually, the new façade was designed in an expressive contemporary language. In fact, the new veranda concentrates the author's greatest creative effort, since here he stated in a more radical way his desire to recover the archetypal shape of the house through modern compositional principles (horizontality, abstraction, simple geometry, tectonic honesty, shadow effects). Nevertheless, the strong influence of the Inquérito also inspired the typological solution as well as the choice of construction techniques reinterpreted from tradition.

One of the main premises was the "conservation and enhancement of all character of the house, making it perfectly livable within a current concept of life" [10], a sentence that reflects the syncretism of this work. Thus, even deep changes were made, Távora was concerned to preserve the main historic values. Hence, the baroque façades were not only fully preserved but the architect decided to give them a greater prominence thanks to the reform of the enclosure in the front yard to increase the visibility from the street. Likewise, the singular arrangement of the house around the central chapel was respected and the noble atmosphere of the representative rooms was preserved, particularly in the main hall and in the master bedroom, which were the only ones that maintained the old decorated wooden ceilings (Figure 4).

\subsubsection{The construction process and details}

It is worth highlighting the way in which Távora combines respect for traditional environments and constructive systems with contemporary functions and a renewed plastic language in the choice of materials and in the definition of the details. In his own words: "all the finishes will be taken care of not only to the function of each piece, but to an overall spirit that without denying the past must be perfectly contemporary" [10]. This issue is reflected in the treatment of carpentries, coexisting interior doors of modern design (simple, stylized and painted white) with preexisting ones of Baroque aesthetic. The architect commanded to preserve as many old elements as possible that were in good condition or that could be repaired.

For its part, the sliding wooden lattice system is the main feature of the new façade. The choice of lattice panels could be taken as a modern reinterpretation of the light wooden enclosures of popular architecture, such as the espigueiros and sequeiros. However, this solution could also be a reference to the latticework that, coming from the Islamic tradition (mashrabiya), remained in Portuguese architecture after the Christian Reconquista. Portuguese builders then brought these elements to Brazil in the colonial period (between the 16th and 18th centuries), taking advantage of its usefulness as a sunscreen and as a privacy filter. Later, in the 20th century, modern architects, such as Lucio Costa and Oscar Niemeyer, creatively reinterpreted them. Távora learned from the influential Brazilian works and redesigned the traditional wooden lattice, creating here a symbol of syncretism between vernacular architecture and modern design [11]

\subsection{Casa da Covilhã (Guimarães, 1963-88)}

\subsubsection{The pre-existing building}

The Casa da Covilhã is a work with a very special meaning in Távora's career since it was his maternal ancestors' country home. Within its walls, gardens and crops, a close bond of identification with the local landscape and culture emerged from his childhood. It is located on the outskirts of Guimarães, in a ring of aristocratic country residences, which emerged during a process of ruralization of the nobility in the $16^{\text {th }}$ and $17^{\text {th }}$ centuries [12].

Like other manor houses, it was built in several phases and went through various stages of enrichment and abandonment. The oldest residential core could have been built at the beginning of the $17^{\text {th }}$ century and was later successively enlarged. Thus, in 1705 it already had a similar physiognomy to the present one, as stated in a document from the Livro de Prazos (record book of credits) of the Convento da Costa: "large house with two floors and attic, with seven windows opened to the south... and a chapel on the nascent side... and warehouses underneath" [13]. In the $19^{\text {th }}$ century the attic was remodeled and a porch was added towards the west [14].

The house passed through several lineages along an intricate chain of successions. Various prominent bloodlines owned this estate until it fell to Fernando Távora by inheritance of his mother [13]. He was fully aware of its long history, of which he was proud: "I knew that she had been begun by João, a schoolmaster and ambassador who died of nostalgia and sadness, had been enriched by Francisca from Baia, and had been ennobled by descendent of Bernardo, the Secretary of the Infante who did not manage to die at Alcácer. She was born again thanks to the money that Luis Antonio had brought from S. João de Rei, was re-awoken by the ire of the other Antonio, the Miguelist canon who would be defeated, was conserved by the austere Adelino, and was much loved by José" [15].

\subsubsection{The intervention strategy}

Upon receiving this legacy, Távora assumed that it was not an ordinary refurbishment, but something much more important, related to his deep sentimental ties to the history of the estate. In fact, he claimed that "it was not a work of architecture, but a work of life" [16]. This strong sense of local identity was also reflected in a metaphorical "love story" he wrote about in the poetic text "We had known each other a long time" [15]. Works were undertaken little by little, as he had time, money and answers to his questions and concerns. This was a prolonged and careful process, "like an act of love, long and slow, insistent and cautious, guided by doubts and 
certainties" [15]. Although works are documented from 1963 to 1988 (following afterwards conservation tasks), the major transformations were carried out between 1973 and 1983.

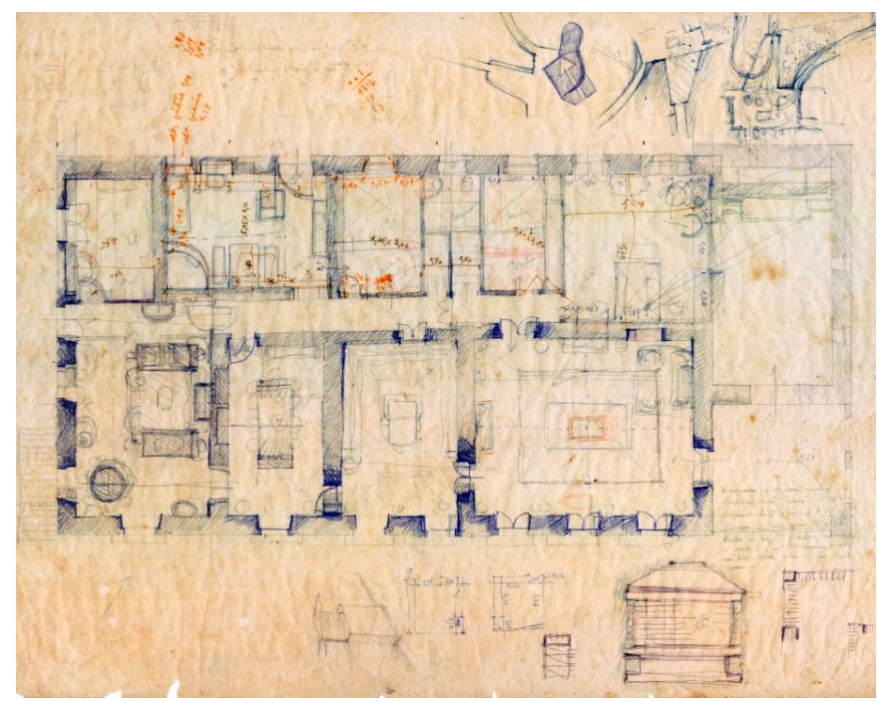

Figure 5. Casa da Covilhã. Schematic survey of the plan. CFundação Marques da Silva, Arquivo Fernando Távora

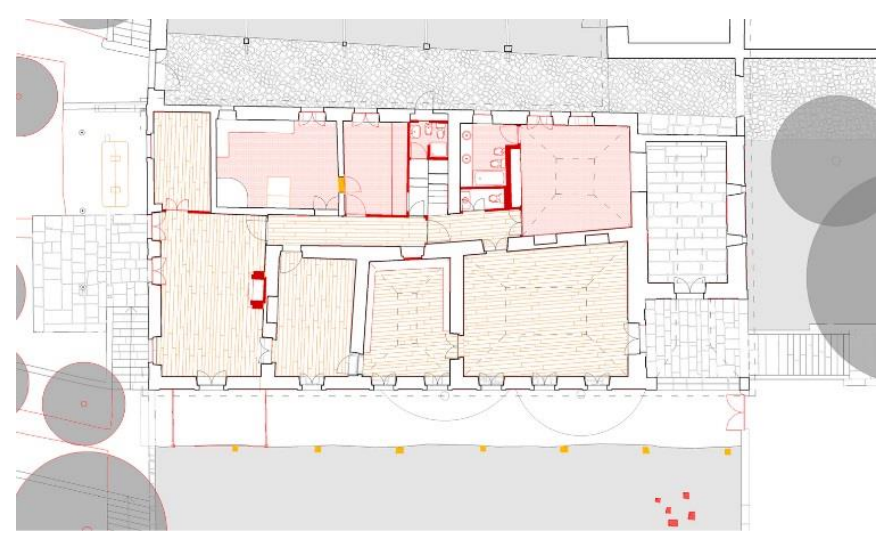

(a) Analysis of transformations

(yellow: demolished elements; red: new elements)

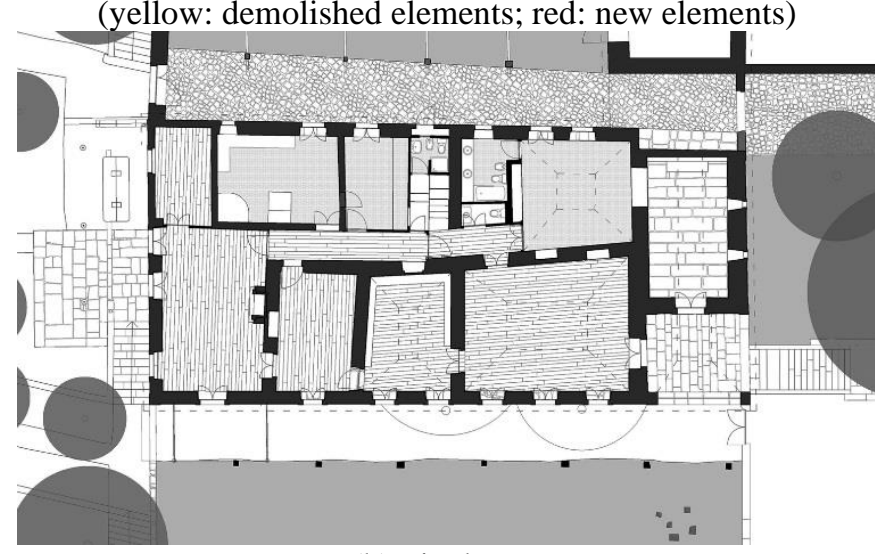

(b) Final state

Figure 6. Casa da Covilhã. Plan of the main floor

In those 10 years, small changes were made that architect and house together "lovingly accepted". It was a project "of passionate man and not of cold technocrat, a project of gestures rather than drawings on paper". Certainly, very few drawings were made. Just a few sketches and a schematic survey of the plan, on which Távora overlapped perspectives, sections, measurements, calculations, studies and proposals at different times (Figure 5). This basic sketch also shows "the imagined experience of spaces", which is a characteristic of his design method: rooms are not simple rectangles and empty squares, but he scrawled on them all the furniture and even the people, their views and their routes.

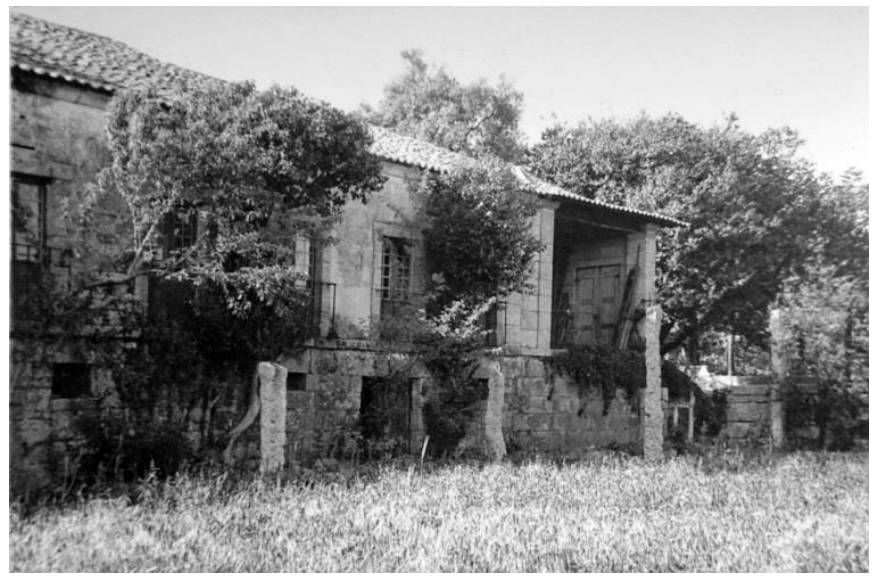

(a) State prior to intervention (Courtesy of J.B. Távora)

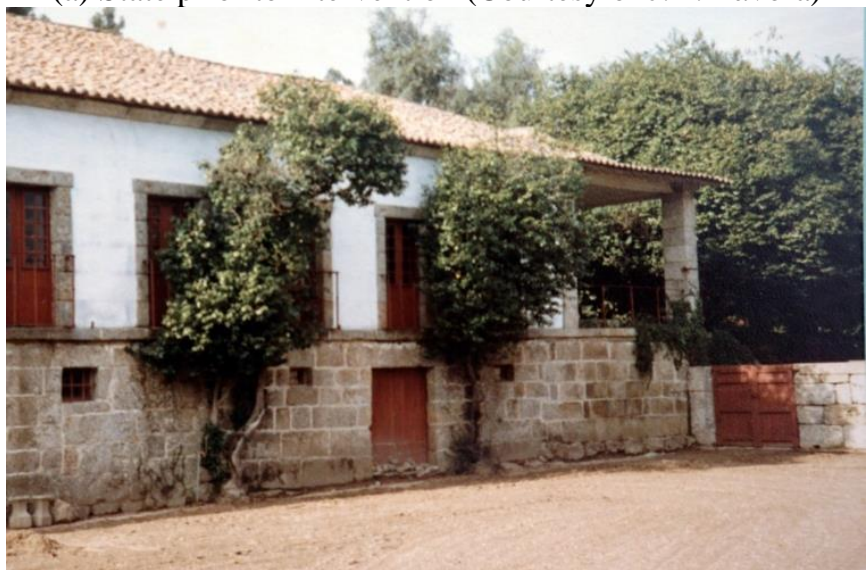

(b) State after the intervention (Courtesy of J.B. Távora)

Figure 7. Casa da Covilhã. Main façade and front yard

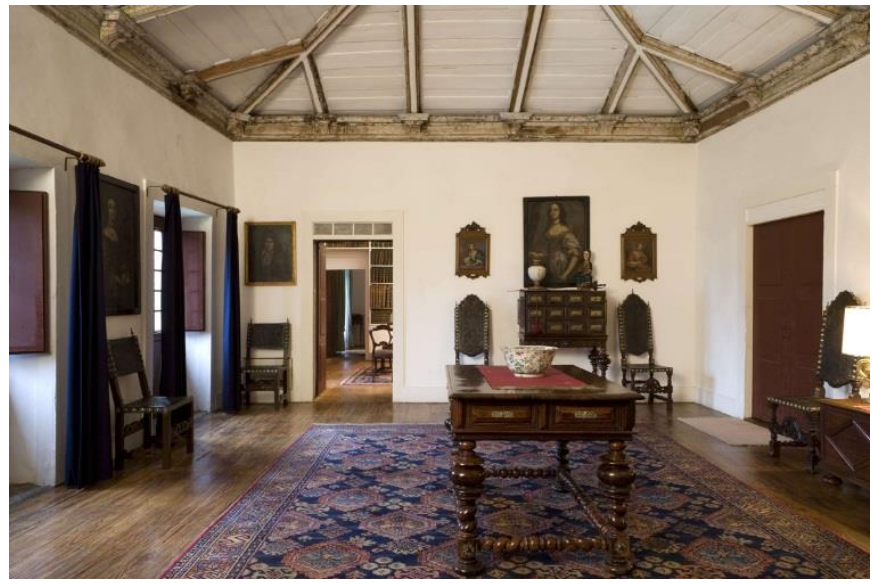

Figure 8. Casa da Covilhã. Main hall

(Luis F. Alves, courtesy of José Bernardo Távora)

Although the house was not in ruins, it had been uninhabited for several years or decades and needed major repairs. Works were mainly consolidation, but also renovation in order to introduce some improvements and amenities (such as toilets, a modern kitchen, new wardrobes, etc.). The refurbishment did not alter the image of the building (Figure 7) and hardly changed the pre-existing spatial arrangement (Figure 6). In fact, one of Távora's main concerns was to preserve the 
genuine historical spirit of the house. Thus, he sought to restore, or even to recreate, the baroque domesticity, in a sense of historical continuity. He arranged a wide repertoire of classic furniture and an extensive collection of art and antiques (paintings, woodcarvings, porcelain, old books, family trees, etc.) in the main rooms of the noble floor (reception room, dining room, sitting room and master bedroom). All these objects contribute to recover and intensify the aristocratic atmosphere of the noble house (Figure 8). Some of these pieces were acquired from antique dealers while others belonged to the family. Contemporaneity in this work has less prominence due to the strong historical identity of the house, although the renovated spaces (such as the toilets and the new closets) reflect a discreet modern design (simplified, white, abstract), seeking a balance between the old aesthetics and an up-to-date expression.

\subsubsection{The construction process and details}

Works were commissioned to master craftsmen, especially a trusted carpenter who took care of the restoration of the roof structure, doors, windows, furniture and other carpentry elements. All actions were carried out little by little, after years of long and deep reflection. Despite the absence of an execution project, the architect frequently came to the site to supervise the works and resolve any doubts or setbacks that arose, in order to maintain a harmonious unity and coherence of the entire work [12].

Távora showed a radical attitude (still unusual in Portugal) regarding the conservation of the constructive elements. He sought to maintain as much as possible, only replacing what was inevitable. Traditional knowledge and techniques were recovered through anonymous repairs, which preserve the material and technological authenticity of the building. This approach is clearly reflected in the repair of the roof. Each and every one of the old tiles was examined, reusing all those that were in good condition and replacing only the deteriorated ones. Instead of substituting them with new tiles, he looked for old ones in demolition works in Guimarães to avoid chromatic dissonances. In addition, he refused to install thermal insulation so as not to alter the traditional construction system. The same approach was taken in the wooden structures, with occasional grafting to clean up the damaged parts. Likewise, instead of replacing the old deteriorated floorboards, Távora ordered them to be numbered, lifted, repaired and placed in the same place, although upside down (to hide the defects). Much of the original woodwork and metalwork was also fixed and preserved. Moreover, he commissioned the progressive restoration of diverse pieces of furniture, paintings, the altarpiece of the chapel as well as the polychromes and the family coat of arms on the ceiling of the main hall.

\subsection{Casa da Breia (Vila Nova de Famalicão, 1984-85)}

\subsubsection{The pre-existing building}

The Casa da Breia is a manor house of ancient origin, located in a fertile rural area with a rich historical context, close to the town of Vila Nova de Famalicão. There are references to the occupation of this place since the XIth century ha [17] however, the first documented mention of the Casa da Breia dates back to 1258, in the Inquirições of King Afonso III. Little else is known until the $18^{\text {th }}$ century, when he Silva lineage (later, Pimenta Aguiar) built a splendid residence over a pre-existing construction, being completed in 1752 (as attested by the inscriptions still visible on the lintels of two windows of the western façade).

The splendor of the baroque palace was seriously disturbed on 1873, when "a dreadful fire broke out in this house, only the family in the house was saved" [18]. The disaster caused an enormous economic prejudice, so the reconstruction works could only be undertaken thanks to the generous donations from relatives. However, the funds were not enough to make the chapel's altarpiece or the sumptuous carved chestnut wood ceilings (as was customary in noble houses in northern Portugal).

Over the decades, these rooms have been inhabited by many different personalities, some of them with captivating lives, who were even taken to literature [19]. A past full of historical events to which the current owner, Dr. Vítor Manuel Figueirido Branco, has contributed. In 1984, he began new renovation works, that were commissioned to the architect Fernando Távora, together with his son, José Bernardo Távora.

Although no archaeological studies were carried out, the architects delved into the history of the house with the purpose of unraveling its evolutionary sequence. Through careful observation and documentary research, Távora reached several conclusions to explain the successive extensions and reconstructions of the building. According to this hypothesis, the core of the residence may be the current "old kitchen", which would have been originally part of a medieval building. Additionally, the west façade, part of the south façade and maybe also the chapel were built in the works of the year 1752 .

The devastating fire of 1873 forced the reconstruction of a large area of the building, a circumstance that was taken in advance to perform additional works. As Fernando Távora detected, the roof was rebuilt with less slope and the position of the cornice was raised to create interior spaces with flat ceilings but grater height (in keeping with the trend of the $19^{\text {th }}$ century), judging by the slight chromatic difference of some of the ashlars that were added just below the cornice. The building was also extended eastwards until reaching the chapel (which would have already been built), as can be deduced from the different thickness and workmanship of the walls.

\subsubsection{The intervention strategy}

Once the historical synthesis had been outlined, Fernando Távora felt qualified to contribute to the building's biography by means of a renovation project that allowed the house to become the occasional residence of the Branco family, while preserving its identity. The architect proposed a reform that pursues a smooth continuity between the pre-existence of the baroque matrix and the transformed parts, sometimes without distinguishing well the beginning and the end of the new and the old matter. The perception of a discreet work begins on the outside, as the façades remain unaltered and only small details warn of the participation of a modern architect (Figure 10).

The central courtyard acts as a cloister, articulating the circulations between the different rooms of the house. Its renovation was the transformation with the greatest impact of the project; however, it has been carried out with great naturalness, making use of materials and techniques taken from tradition although slightly updated to give a more contemporary appearance. The operation consisted of cutting the length of the impluvium, generating instead an in-between living room pleasantly illuminated by a large window (Figure 11). This reform involved altering the configuration of the roof skirts (carried out with skillful spontaneity) and replacing the rudimentary enclosures with sophisticated carpentry of traditional inspiration. The new glazed gallery on the first floor 
brings luminosity, transparency and great unity through the chromatic treatment: white for the woodwork and blood-red tone on the parapets and eaves. This gallery rests on the linteled structure of bush-hammered concrete and granite that covers the peristyle of the ground floor. A pre-existing exterior granite staircase communicates both floors through the patio.

Other parts of the house were subtly modified by small architectural surgeries: modifying compartments, opening or closing gaps, adding toilets, reorganizing the kitchen... (Figure 9). In addition, the renovation of the library was drawn in detail, carefully specifying the features of the bookshelves, paneling, moldings and fireplace. This room shows a modern design in terms of simplicity of lines and monochromatism. However, the classical arrangement of its elements evokes aristocratic refinement. Although the house lacks the sumptuousness of other neighboring noble mansions due to the damage of the fire, the sobriety of the finishes, the casual combination of classic and contemporary furniture (chosen by the owner) and the prominence of Mr. Branco's contemporary painting collection give the house a sober but elegant spirit.

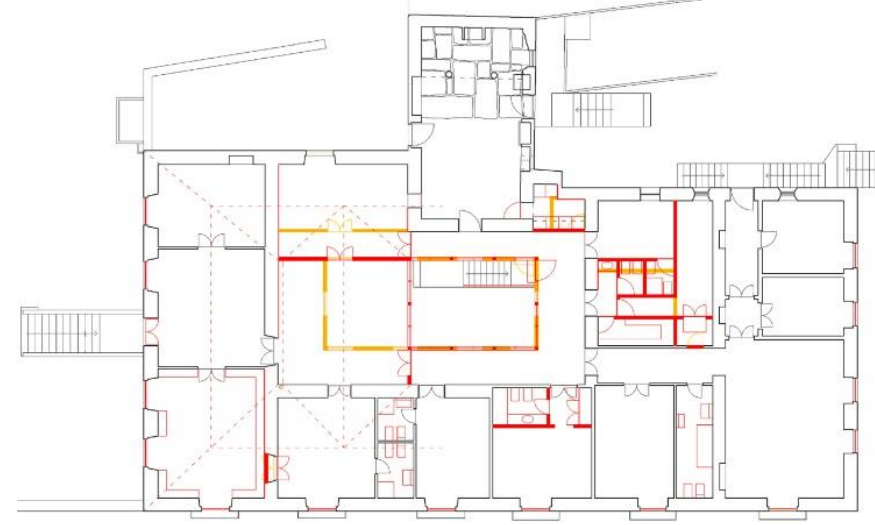

(a) Analysis of transformations

(yellow: demolished elements; red: new elements)

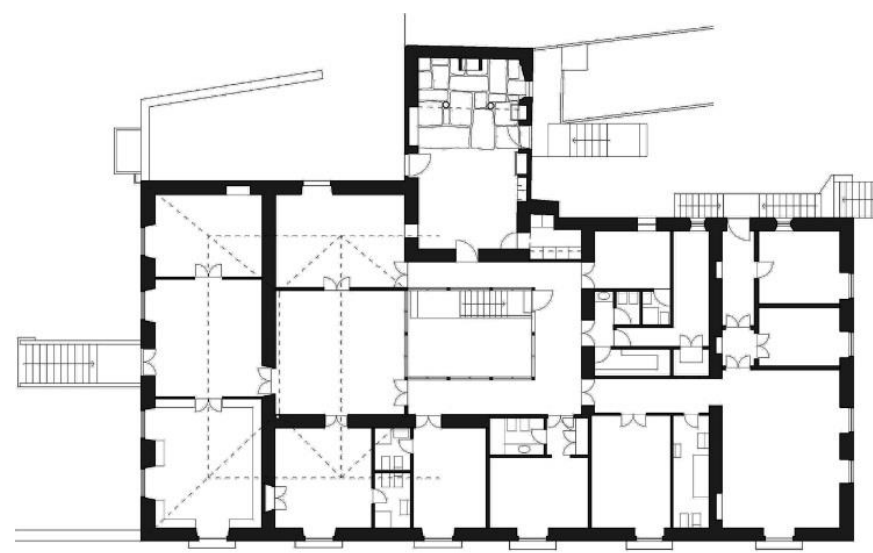

(b) Final state

Figure 9. Casa da Breia. Plan of the main floor

\subsubsection{The construction process and details}

Although rigorous execution plans were made, the works had a highly artisanal character. A trusted carpenter carried out the woodwork and the architect constantly supervised the works to solve in situ any problems that might arise (Távora visited the site up to 38 times).

Regarding the treatment of carpentry and finishes, the project specifications reveal the coexistence of new and old elements. It specifies that the interior doors and trimmings must be maintained, reusing in new locations those from demolished compartments. Likewise, the old baseboards were conserved and others of simplified design, inspired by the previous ones, were installed where preservation was not possible. The ceilings, which, however, had no special value, were all replaced by a plain stucco. Both the carpentry of the patio and the access door and other exterior windows were made again following a traditionally inspired design.

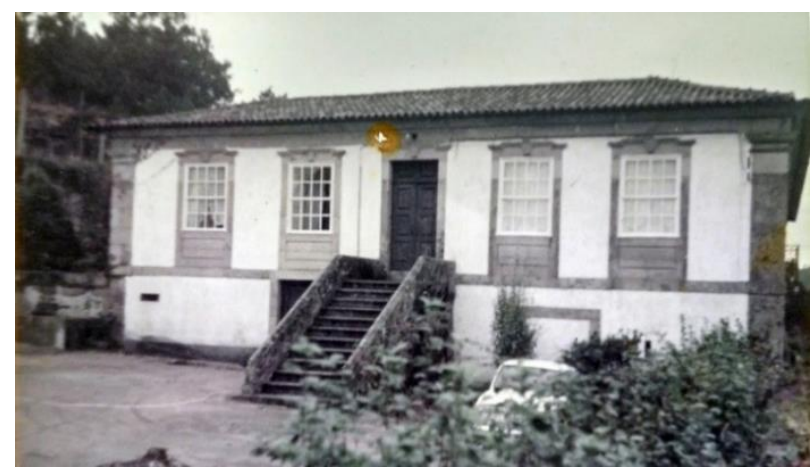

(a) State prior to intervention

CF Fundação Marques da Silva, Arquivo Fernando Távora

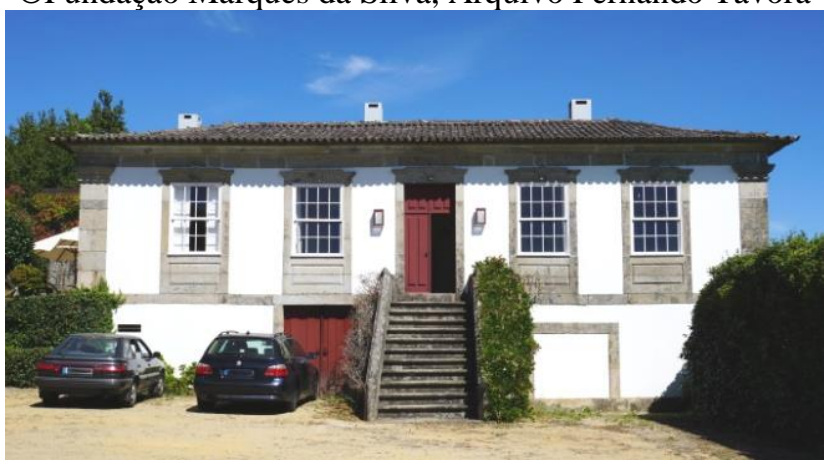

(b) Current state

Figure 10. Casa da Breia. West façade

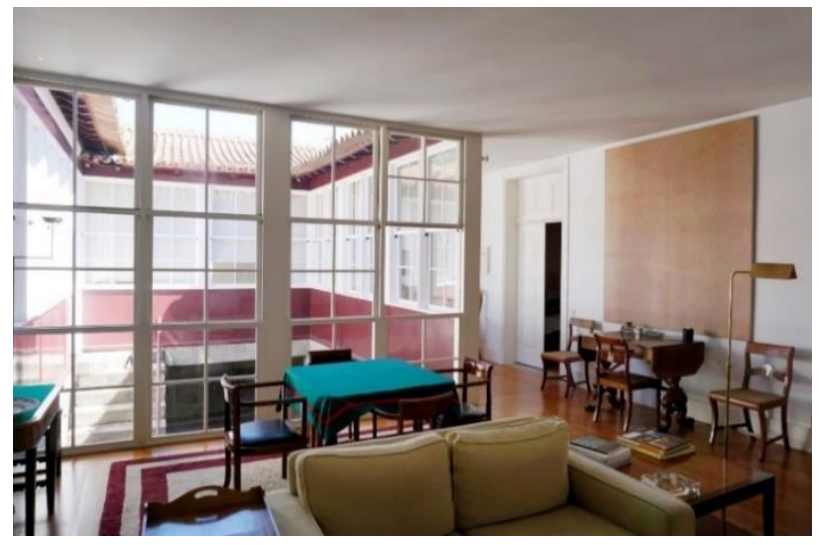

Figure 11. Casa da Breia. New living room next to the patio

\section{DISCUSSION}

This chapter provides the discussion of the findings from the three case studies by means of the abovementioned methodology and parameters.

\subsection{The pre-existing building}

In the three cases, actions were always preceded by a thorough analysis of the building and its context. Prior to any 
change, Fernando Távora interpreted landscape (identifying the values and identity characters to be preserved), looked for historical documentation, studied the genealogy of the owners and carefully scrutinized the walls in search of joints, "scars" and constructive evidences to interpret the evolutionary sequence of the building. He was interested in learning about the building's past to insert his proposal in a respectful continuity with the compositional patterns of the preexistence. Thus, his purpose was to integrate the new architecture "in the continuous and temporally extensive formal processes of the pre-existences, creatively dominating and controlling their invariants, in such a way as to prolong their identity and their spirit" [12]. His contribution would be just one more layer in the already long history of the buildings, neither more nor less relevant than the previous ones. Likewise, the cautious prior studies reveal a "case-by-case" approach, according to which the design of each project depends on the specific circumstances of the context, refusing predetermined solutions or axiomatic principles.

The understanding of specific historical processes gave him the hints to base his designs. In the Casa da Igreja, the modern reinterpretation of the rear façade is based on the knowledge of the building's original typology. At Casa da Breia, the design of the new patio came about after understanding the building's turbulent past. Meanwhile, in the Casa da Covilhã, the deep emotional ties with the house and the awareness of its history invited him to carry out extraordinarily respectful and restrained operations.

\subsection{The intervention strategy}

The three case studies demonstrate how Távora struggled to respectfully preserve those identifying elements that he considered to have architectural or constructive value, in order to conserve and enhance the "spirit" of the building. Nor can it be forgotten that Távora belonged to the rural aristocracy, so he was familiar to this type of buildings. Besides his vast architectural culture, he was an expert collector of antiques and a specialist in Portuguese decorative arts.

The scale, symmetry, axes, geometric proportions, the organization of spaces or the circulation schemes of the preexistence were issues that he considered essential to respect, whether the intervention showed a more conservative or modern language. Thus, although the three cases are different, they all share the common desire to preserve or recover the typological purity of the building. Therefore, in Mondim he emphasized the central role of the chapel and removed all the volumes that distorted the original profile of the house; in Breia, the renovation of the patio was inspired by the typical wooden glazed galleries of the 19th century and in Covilhã the reform hardly alters, but rather enhances the classical character of the building.

Moreover, in all three cases the main façades (those that show greater compositional harmony and decorative concern) were carefully preserved. In the baroque stately architecture, the exterior-oriented façades have a symbolic, scenographic and social affirmation character, features that Távora intended to preserve and even emphasize. Likewise, the most representative rooms (such as the reception room, the living room, the master bedroom and the library) maintained their aristocratic atmosphere. Hence, the sumptuous wooden ceilings were preserved where possible (Covilhã, Mondim) and furniture and pieces of classical art were restored and/or acquired (in the Casa da Breia combined with others designed by Távora). Both actions (preservation of façades and emblematic rooms) constitute a constant feature of Távora's method, strongly associated with the desire to "keep visible a consolidated historical image of the existing building" [20]. Also, where it was necessary to replace a damaged part or restore a missing gap, clearly distinguishable elements were not inserted, but simplified pieces instead (abstractions from the original ones) that barely reveal the repair work so as not to disturb the perception of the whole, but without falsifying the past. In these circumstances, Távora creates a kind of ambiguous atmosphere between the past and the present, in which an inattentive gaze would not perceive any discontinuity or rupture between the new and the old material.

However, philology and accuracy did not inhibit Távora form freely carrying out some in-depth transformations that enabled functional updating, as well as other operations to improve the conditions of hygrothermal comfort and functionality. The most substantial transformations, to which the architect devoted greater creative efforts, are those placed in less visible or socially representative parts, formerly dedicated to auxiliary or domestic functions. These rear façades were originally constructed with lower quality materials and lacked a careful composition, as it happened in Casa da Igreja or in the Casa da Breia. Then, the architect decided to design new structures that reveal contemporary reinterpretations of the Portuguese constructive tradition, which he had deeply studied in the Inquerito. Távora felt comfortable in these kind of situations, as he managed to create new intervention while using traditional techniques, both with a modern appearance and pretension of timelessness. He also achieved great unity and integrity in the result, using, among other resources, simple but effective color codes to unify new and old elements.

\subsection{The construction process and details}

The comparison between chronologically distant cases shows a clear evolution of his proposals; moving from a resounding modernity, vividly expressed in the rear facade of the Casa da Igreja, towards a much more subtle contemporaneity, concealed within the anonymity of the traditional inspired solutions of Covilhã and Breia. Távora progressively left behind the modern formalism of the 1950s to adopt a more subtle and restrained expression, strongly rooted in local constructive culture. Indeed, he did not renounce modernity in his time of maturity, but it is condensed into subtle gestures, in the design of some elements such as carpentry, lighting, furniture, cooler patterns, among others.

Távora's own house in Covilhã is an extreme example of what he described as "cane architecture", that is, building almost without plans, since the works began with only a few sketches and the architect gave instructions directly to the workers on site. Although in Breia and Mondim there was an execution project, both constructions also had a strong artisanal character, thus obtaining more freedom to alter the initial proposal as the work developed (making decisions at the construction site that were never put down on paper). However, this greater flexibility also compelled him to constantly supervise the construction in order to ensure the unity and coherence of all the works. Távora trusted the craftsmen (experts in the traditional techniques of masonry and carpentry) with whom he liked to talk and discuss the solutions on the building site.

Indeed, the Casa da Covilhã is a very representative case of 
an intervention attitude deeply sensitive to the material and technological authenticity of the building, in which traditional techniques and know-how were recover to carry out extremely delicate and anonymous repairs. However, the preservation of local constructive materials did not preclude the use of modern conventional systems in the reformed or enlarged parts, such as reinforced concrete slabs. Some renovations even required in-depth transformations, as in the case of the Casa da Igreja, which involved great spatial and structural alterations.

\section{CONCLUSIONS}

The renovation projects of manor houses performed by the Portuguese architect and professor Fernando Távora are valuable examples of an intervention method that allows for the adaptive reuse of these old buildings, responding to the needs of a current lifestyle while respecting their identity within the landscape and heritage values.

Távora's conservation and renovation design methodology is characterized, first, by the prior study of the building and its context in order to integrate the new architecture in continuity with the historical processes. Another important feature is the rigorous preservation of the elements with greater architectural value and symbolic character, such as the main façades and social reception rooms. On the other hand, parts of the building with lower value may be carefully altered to incorporate new functions and update the image of the building through a creative reinterpretation of the constructive tradition.

Távora achieved final results of great harmony between the new and old parts through apparently anonymous but subtle modernity interventions. Works were commissioned to trusted artisans, experts in traditional techniques, and many times were executed without definitive plans, although constantly supervised by the architect on site to ensure the unity of all operations. Anyway, all decisions were supported by a deep knowledge of the building's past and its cultural context, in a sense of permanent modernity: understanding the lessons of history and its constants to "continue innovating" while preserving the identity and values of these manor houses for the future generations.

\section{ACKNOWLEDGMENTS}

This work is part of the doctoral research that the first author is developing thanks to a $\mathrm{PhD}$ scholarship awarded by the University of the Basque Country UPV/EHU. The study was co-financed by the European Regional Development Fund (ERDF) through COMPETE 2020 and by national funds through FCT, under the scope of the POCI-01-0145-FEDER007744 project. The authors acknowledge the collaboration of the Marques da Silva Foundation (FIMS). We are also indebted to the kindness of those who provided us with information and facilitated access to the case studies.

\section{REFERENCES}

[1] Ordóñez-Castañón, D., Cunha-Ferreira, T., SánchezBeitia, S (2020). Intervention in vernacular architecture: the lesson of Fernando Távora. The International Archives of Photogrammetry, Remote Sensing and Spatial Information Sciences, 44: 123-130. https://doi.org/10.5194/isprs-archives-XLIV-M-1-2020123-2020

[2] Stoop, A. (1993). Palácios e Casas Senhoriais do Minho. Civilização, Porto, 9.

[3] Sindicato Nacional dos Arquitectos (1962). Arquitectura Popular em Portugal, S.N.A., Lisboa.

[4] Goodwin, P. (1943). Brazil Builds, Architecture New and Old, 1652-1942. MoMA, New York.

[5] Fernandes, E. (2019). The construction of the Porto School. In Structures and Architecture-Bridging the Gap and Crossing Borders. CRC Press, 1017-1023. https://doi.org/10.1201/9781315229126-121

[6] Ferreira T. (2007). Sulla storia del restauro in Portogallo: provvedimenti, protagonista, interventi. Anake: cultura, storia e tecniche della conservazione, 52: 78-95.

[7] Ordóñez-Castañón, D., Cunha-Ferreira, T., SánchezBeitia, S. (2019). Towards a new approach of architectural heritage intervention in Portugal: Fernando Távora and the refurbishment of the Casa da Igreja of Mondim de Basto (1958-1961). WIT Transactions on The Built Environment, 191: 187-198. https://doi.org/10.2495/STR190161

[8] Távora, F. (1985). Pousada de Santa Marinha: Guimarães. Boletim da DGEMN, 130.

[9] Portas, N. (1961). Arquitecto Fernando Távora: 12 anos de actividade profissional. Arquitectura, 71: 11-33.

[10] Távora, F (1958). Casa da Igreja (memória do anteprojeto). Arquivo da Fundação Marques da Silva.

[11] Ordóñez Castañón, D., Cunha Ferreira, T., de los Ojos Moral, J. (2019). De la tradición a la modernidad: la reinterpretación de la celosía de madera. Influencias recíprocas entre Brasil y Portugal. Anais do $3^{\circ}$ Congresso Internacional de História da Construção Luso-Brasileira, 899-913.

[12] Ferrão, B. (1998). Casa da Covilhã. DPA, 14: 42-45.

[13] Pereira de Moraes, M.A. (2001). Velhas casas de Guimarães (vol. 1). Centro de Estudos de Genealogía, Heráldica e História da Família da Universidade Moderna do Porto, 99-126.

[14] Esposito, A., Leoni, G. (2004). Fernando Távora. In: One hundred houses for one hundred architects of the twentieth century. Taschen, Köln, 382-385.

[15] Távora, F. (1993). Casa da Covilhã, Guimarães, 1973 1976. In: Fernando Távora. Blau: Lisboa, 128-133.

[16] Ortiz Orueta, J.A. (2015). En el principio era Távora: itinerario para la transmisión de una síntesis arquitectónica ( $\mathrm{PhD}$ Thesis). UPM, Madrid. http://oa.upm.es/40517/.

[17] Barroca, M.J., Silva, A.C.F. (2018). Mil anos da incursão normanda ao Castelo de Vermoim. CITCEM, Porto.

[18] Pinho Leal, A., Ferreira, P.A. (1873). Portugal antigo e moderno. Mattos Moreira \& Co. Lisboa, 310-311.

[19] Stoop, A. (2015). Arquitectura Senhorial do Minho. Caminhos Romanos, Porto, 173-175.

[20] Leoni, G. (2005). Oltre il "moderno": L'architettura di Fernando Távora. In: Fernando Távora: opera completa. Electa, Milano, 62. 